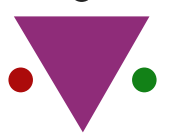

IJCRR

Section: Healthcare

Sci. Journal Impact

Factor: 6.1 (2018)

ICV: 90.90 (2018)

cc) (7) (8)

Copyright@IJCRR

\title{
Comparative Study on Haematological Parameters in Leech Application for Acute Inflammation
}

\section{Rucha Narendra Selkar ${ }^{1}$, Kiran Khandare ${ }^{2}$, Manoj Patil ${ }^{3}$, Chetan Gode ${ }^{4}$}

\section{ABSTRACT}

Background: Ayurveda believes Raktamokshan to be an idiosyncratic minor operative procedure useful in treatment for letting blood in conditions where blood is vitiatedancient sages of Ayurved like Acharya Sushruta, who is considered as the father of ancient Indian surgery narrates about normal and disturbed functioning bit part of Rudhira and its major role in various operative methods. More than a bloodletting therapy, an amazing cocktail of medicinal substances is present in the salivary secretions of the leech. This has led to its therapeutic utilization in countless medical and surgical ambiences. About the environment and normal body conditions, parameters related to blood are essential. The foreign bodies present in blood can be disclosed from the evaluation of haematological and differential parameters. The estimation of this criterion: Erythrocytes, leukocytes and thrombocytes give the approach to evaluate the presence of assorted module in the blood of animals which is been instrumental in pathological, physiological, and nutritional status of animals.

Objectives: To Evaluate of Haematological Parameters of Leech Application in Acute Inflammation by assessing the changes in the haematological parameters (CBC with ESR) before and after $24 \mathrm{hrs}$ of leech application in acute inflammation.

Methodology: 20 Patients of age group between 20 to 50 years of either sex with acute inflammation indicated for leech therapy will be selected, Nirvisha leech used for medicinal purpose Hirudo medicinalis will be applied and haematological changes will be compared before and after leech application.

Results: After data analysis results will be noted.

Conclusion: Few changes will be seen in haematological parameters.

Key Words: Raktamokshan, Haematological, Leech, Acute inflammation

\section{INTRODUCTION}

Ayurveda believes Raktamokshan to be an idiosyncratic minor operative procedure useful in treatment for letting blood in conditions where blood is vitiated. Ancient sages of Ayurved like Acharya Sushruta, who is considered as the father of ancient Indian surgery narrates about normal and disturbed functioning bit part of Rudhira and its major role in various operative methods. More than a bloodletting therapy, an amazing cocktail of medicinal substances is present in the salivary secretions of the leech. This has led to its therapeutic utilization in countless medical and surgical ambiences. About the environment and normal body conditions, parameters related to blood are essential. The foreign bodies present in blood can be disclosed from the evaluation of haematological and differential parameters. The estimation of this criterion: Erythrocytes, leukocytes and thrombocytes give the approach to evaluate the presence of assorted module in the blood of animals which is been instrumental in pathological, physiological, and nutritional status of animals. ${ }^{1}$ Salutary prosecution of leeches pace to the dawn of sophistication ${ }^{2}$. The drastic and magical effect of leech has been found in inflammatory disorders. Stereotypically leech was cast off for numerous inflammatory disorders ${ }^{[1]}$. When a group of cells are damaged the immune system gets activated and produces antigens against a foreign body which results in cardinal signs like redness, swelling, raised temperature, loss of movement and pain is Acute inflammation.

\section{Corresponding Author:}

Rucha Narendra Selkar, Intern, Batch 2015-2016, Mahatma Gandhi Ayurved College Hospital \& Research Centre, Salod (H.), Datta Meghe Institute of Medical Sciences, Wardha, Maharashtra, India; Contact: 9730381904; Email: selkarrucha25@gmail.com

ISSN: 2231-2196 (Print)

Received: 28.09 .2020
ISSN: 0975-5241 (Online)

Revised: 20.10 .2020
Accepted: 11.11 .2020
Published: 30.11 .2020 
Leech Therapy is claimed to be the supreme therapy because of its advance capability in the healing diseases of blood. ${ }^{2}$ The therapeutic procedure of raktamokshan has been of great importance since ages. Antichrists speculated to cause ailment and eviction of these antichrists craved blood withdrawal. Egyptian tombs anteceded to $1500 \mathrm{~B}$. C founded the illustrations of leech application to patients. Sanskrit, Arabic and Persian literature have also cited the extraction of blood from the human body by application of leech. Alexipharmaca by Nicander of Colophon during 200-130 B.C. the therapeutic application of leech was documented for the first time in his poem. ${ }^{3}$

Both Sushruta and Vagbhata included leech under Anushastra. According to Charaka, it is one among Shastra Pranidhana ${ }^{6}$. Sharanghadhara says in course of urgency, Raktamokshan can be done through leech therapy in contraindicated patients too. Leech sucks the impure (Dushta) Rakta which is compared with the simili like $a$ swan which can differentiate the milk from water if mixed. ${ }^{7}$

Jalaukavacharan was the ancient technique of letting blood by Ayurveda. ${ }^{1}$ It was believed that leech was evolved by divine power lord Dhanwantari at the time of samudramanthan along with the nectar-filled pot. Among various other instruments used for bloodlettings like Shriga, Alabu, Jalauka and Siravedh - Jalaukavacharan (Leech Therapy) was easiest and safe methods. ${ }^{2}$ It has been documented in a book of Avicenna in the year 980-1037 AD "Cannon of Medicine" that wet cupping is also not much effective for sucking deep venous blood as Leech does. ${ }^{8,9}$

It is found that the application of Leech (leech therapy) is being widely used day by day. As the treatment is very effective, painless for certain inflammatory disorders patients prefer it as far as possible, so it is necessary to evaluate the effect on haematological parameters in acute inflammation.

\section{OBJECTIVES}

1. To put forth the haematological (CBC with ESR) changes before leech application in acute inflammation.

2. To put forth the haematological (CBC with ESR) changes after leech application in acute inflammation.

3. To compare the changes in haematological parameters (CBC with ESR) before and after the leech application.

Case definition- 20 to 50 years patient with complaints of acute inflammation of either sex indicated for leech therapy will be considered as a case for this study ( figure 1).

Research Question: Is there any changes in the haematological parameters before and after leech application in acute inflammation.
Hypothesis: There may be few changes in CBC with ESR before and after leech application in acute inflammation due to its saliva having multiple contents.

Null Hypothesis: There may not be any changes in CBC with ESR before and after leech application in acute inflammation.

\section{MATERIALS AND METHODS}

Trial design: The study will be the comparative type with 1:1 ratio having two parallel groups (figure 1).

METHOD: Nirvisha leech ${ }^{10}$ used for medicinal purpose Hirudo medicinalis. ${ }^{11}$

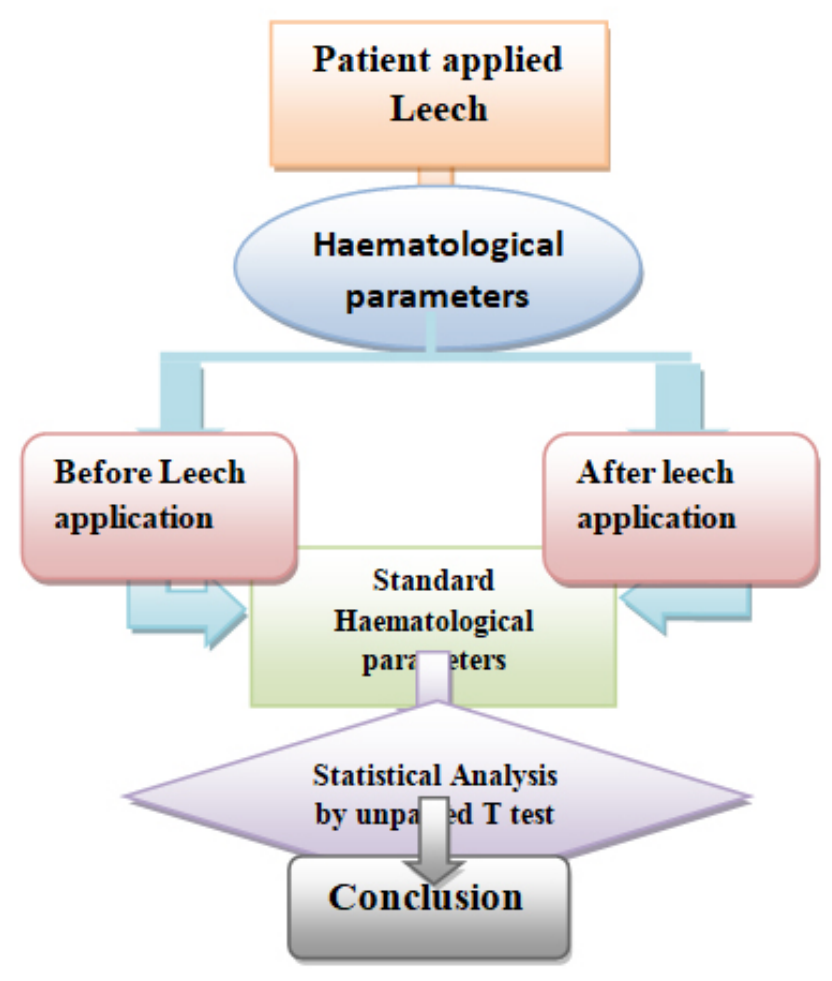

Figure 1: Study design.

Study setting: At Shalya Tantra OPD of MGACH and RC, Salod $(\mathrm{H})$, Wardha.

Eligibility criteria: Patients age group between 20 to 50 years of either sex with acute inflammation indicated for leech therapy visiting Shalya Tantra OPD will be selected. Patients with HIV and HbsAg positive and any other Medical emergency will be excluded (Table 1). 
Table 1: Standard Haematological parameter.

\begin{tabular}{lll} 
Sr. no Haematological & Male & Female \\
parameters & & \\
Haemoglobin g/Dl & $14-16 \%$ & $11-14 \%$ \\
TLC & $4000-11000 /$ & $4000-1100$ / \\
& cumm & cumm \\
DLC-Neutrophils & $40.75 \%$ & $40.75 \%$ \\
Lymphocytes & $20.45 \%$ & $20.45 \%$ \\
Monocytes & $1.6 \%$ & $1.6 \%$ \\
Eosinophils & $2.10 \%$ & $2.10 \%$ \\
Basophils & $0.2 \%$ & $0.2 \%$ \\
Total RBC count & $4 \cdot 5-5 \cdot 5 \mathrm{million}$ & $4.5-5 \cdot 5$ \\
& per cubic mm & million per \\
& & cubic mm \\
PLATELETS & $1,50,000-$ & $1,50,000-$ \\
& $4,50,000 \mathrm{~mm}$ & $4,50, \mathrm{ooomm}$ \\
PCV & $42-52 \%$ & $36-48 \%$ \\
ESR Westerngreen & $0-15 \mathrm{~mm} / \mathrm{hr}$ & $0-20 \mathrm{~mm} / \mathrm{hr}$ \\
method & & \\
MCV & $80.97 \mu \mathrm{md}$ & $80.97 \mu \mathrm{md}$ \\
MCH & $26.5-33 \cdot 5 \mathrm{pg}$ & $26.5-33 \cdot 5 \mathrm{pg}$ \\
MCHC & $31.5-35 \cdot 5 \%$ & $31 \cdot 5-35 \cdot 5 \%$ \\
BT & $1-3 \mathrm{~min}$ & $1-3 \mathrm{~min}$ \\
CT & $3-9 \mathrm{~min}$ & $3-9 \mathrm{~min}$ \\
\hline
\end{tabular}

Study size: 20

Total months of study: 3

Statistical analysis: Unpaired T-test to be applied for statistical analysis.

We will select the patient with acute inflammation indicated for leech therapy as per eligibility criteria. Confirmed eligible will be included in the study.

Period for follow up: 0 days.

Enrolment and interventions Time: Before sample on $0^{\text {th }}$ day, the leech will be applied on the same day and after therapy sample will be taken.

Recruitment: 20 patients with acute inflammation indicated for leech therapy will be recruited by PI and verbal written consent.

Method for Collection of Data: Assessment criteria.

Objective criteria- CBC with ESR will be done before and after the leech application. The patient will be advised selfobservation and contact for any sort of infection or untoward effects, gathered data will be documented with reason.

Statistical method: for data analysis Unpaired T-test will be applied.

Ethics and dissemination: Ethical approval from Institutional Ethics Committee, Datta Meghe Institute of Medi- cal Sciences, (Deemed to be University), Wardha. (Ref. No DMIMS(DU)/IEC/Aug- 2019/8312, dated 10/09/2019).

Consent: At the very beginning verbal and written consent will be taken from the patient also will be looking forward to the maintenance of confidentiality of both included and excluded patients.

Informed consent materials: Participants will be provided with a proper informative Model consent form and other related documents copy.

\section{EXPECTED OUTCOMES}

As the leech application is broadly used as a para-surgical procedure nowadays so the magical effect will be seen in acute inflammation too. Changes will be seen in ESR, TLC and DLC values will be found to variable in minor aspect. Total RBC count may decrease, platelets count will be increased changes can be seen due to raised infection. Minute changes will be noted in PCV, MCV, MCH, MCHC. Due to anticoagulant content in leech saliva drastic changes will be seen in BT and CT. Changes may not be found in Hb. Actual changes will be shown after analysis through various charts and diagrams.

Dissemination policy: Paper publication will be used for data dissemination.

\section{DISCUSSION}

Disinfected leeches Poecilobdella Viridis (Blanchard) were fed on the blood of healthy human (male and female) volunteers to know the immediate biochemical alterations in human blood. Hirudo medicinalis suck polling blood. Skin tissues of patient are firmly held by the leech with its teeth which are made of calcite. Histamine helps in vasodilatation of bitted vessels. Salivary glands are present with gelatinolytic activity reported by Damas. ${ }^{12}$ Hirudin forms a complex with thrombin inhibiting its activity, resulting in bleeding for a long time affecting the coagulation process. Most of the volunteers exhibited decreased haemoglobin after leeching and this decrease was significant after application of more than two leeches. Few results imply that leech saliva contains proteases and lipases which might have digested the RBC membrane proteins and lipids and also the globulin from haemoglobin. ${ }^{13}$ Application of one leech has also resulted into increase in RBC count, which indicates a factor in leech saliva having the capacity to activate the erythropoiesis. The present study will show the haematological alterations in the human blood -before, just after and after $24 \mathrm{hrs}$ of the application of leeches. 


\section{CONCLUSION}

Conclusion will be drawn based on results and observations. Multiple changes will be noted as per the results mentioned above in ESR, TLC, DLC, RBCs, platelets, BT, CT.

Strengths: Before, early and late changes can be noted to grow the wide use of leech therapy.

Limitations: Changes can be more precise after the second set of the leech application.

\section{ACKNOWLEDGMENT}

Authors acknowledge the immense help received from the scholars whose articles are cited and included in references to this manuscript. The authors are also grateful to authors / editors / publishers of all those articles, journals, and books from which the literature for this article has been reviewed and discussed.

\section{Conflict of Interest: Nil}

Funding: Intramural funding - Datta Meghe Institute of Medical Sciences

\section{REFERENCES}

1. Shastri A. Sushruta Samhita Ayurved Tattva Sandipika Hindi Commentary, Edition: Reprint Sutra Sthana. Varanasi; Chaukhamba Sanskrit Samsthana; 2016; 13(3):57.

2. Miles J. Medical use of Medicinal leeches. University of Connecticut Dept of Molecular and Cell biology: [Internet] 2017 april [Cited 2017 Jun 21] Available: http://www.uconn.edu/mcbstaff/graf/Medical/html

3. Shastri A, Sushruta Samhita Ayurved Tattva Sandipika Hindi Commentary, Edition: Reprint Sutra Sthana. Varanasi; Chaukhamba Sanskrit Samsthana; 2016; 13(3):61.

4. Shastri A. Sushruta Samhita Ayurved Tattva Sandipika Hindi Commentary, Edition: Reprint, Sutra Sthana, Chapter 8 Verse 15, Varanasi; Chaukhamba Sanskrit Samsthana; 2016. p. 39.

5. Murthy KRS. Vagbhatt's Ashtang Hridayam, Edition: Reprint Sutra Sthana, Chapter 26 Verse 27 Varanasi; Chaukhamba Krishnadas Academy; 2007;302.

6. Shastri K. Charaka Samhita Vidyotani Hindi Commentary, Edition: Reprint, Sutra Sthana Chapter 11, Verse 55, Varanasi; Chaukhamba Bharati Academy 2016; 239.

7. Srikanth K, Murthy R. Vagbhatt's Ashtang Hridayam, Edition: Reprint, Sutra Sthana, Varanasi: Chaukhamba Krishnadas Academy; 2007; 305.

8. Whitaker IS, Rao J, Izadi D, Butler PE. Historical article: Hirudo medicinalis: Ancient origin of, and trends in the use of medicinal leeches throughout history. Br J Oral Maxillofac Surg 2004;42:133-7.

9. Munshi Y, Ara I, Rafique H, Ahmad Z. Leeching in History- A review. Pak J Biol Sci 2008;111650-3.

10. Sharma A. Sushrut Samhita of Maharshi Sushruta. Edition: Reprint, Sutra Sthan, Chapter 13 Verse 12. Varanasi. Choukhamba Surbharati Prakashan; 2012; 96.

11. Sig AK, Mustafa G, Guclu. Medicinal leech therapy-an overall perspective. Integr Med Res 2017;(6):337-343:

12. Damas D. Etude histologique et histochimique des glands salivaries de la sangsue medicinale Hirudo medicinalis (Hirudinee, Gnathobdelle). Arch zool exp. (Paris) 1974;155: 279-292.

13. Deshmukh SS, Varshney SS, Wankhede GN. Haematological alterations in human blood after leech application. IJMG 2012;2:1-10 